\title{
Editorial: Research into structural concrete
}

\section{Robert L. Vollum}

Department of Civil and Environmental Engineering, Imperial College of

Science, Technology and Medicine, London, UK

This themed issue of the Magazine of Concrete Research includes eight papers that have been chosen to reflect the diversity of current research into structural concrete. None of the papers were specially commissioned for the issue. A striking feature of all the papers is that they involve experimental work, as well as analytical modelling, which illustrates the continuing importance of structural testing in concrete research.

Five of the eight papers are concerned with shear which is perhaps the most researched of all areas in reinforced concrete design. The article by Vaz Rodrigues (2012) addresses the significant matter of the influence of yielding of flexural reinforcement on shear transfer through cracks. This matter has come to the fore with the publication of the draft fib Model Code 2010 (fib, 2012) which is an important document as it is likely to form the basis of future revisions to Eurocode 2 (2004). Model Code 2010 follows the recommendations of Collins et al. (2008) in relating the shear resistance provided by the concrete to the strain in the flexural reinforcement. This is a departure from Eurocode 2 and the now withdrawn British Standard BS 8110 (2007) which relate the shear resistance of members without web reinforcement to the flexural reinforcement ratio. Vaz Rodrigues et al. (2010) have previously raised the concern that statically indeterminate members can fail in shear after the formation of the first plastic hinge prior to reaching their design load. Considerations like these suggest that tests on statically determinate beams may not be a good indicator of the performance of continuous beams where significant moment redistribution can occur following the development of the first plastic hinge. Therefore, there appears to be a need for further tests to study the effect of yielding of flexural reinforcement on the shear resistance of continuous beams.

The paper by Yang et al. (2012) is also concerned with the shear transfer but this time with shear transfer through monolithic concrete joints. In this case, concrete is modelled as a rigidperfectly plastic material that reflects the diversity of modelling approaches for structural concrete. The paper by Motamed et al. (2012) considers the influence of horizontal web reinforcement on shear resistance. The article focuses on the contribution of dowel action which is not widely considered in shear design.

The paper by $\mathrm{Lu}$ et al. (2012) considers the behaviour of reinforced concrete dapped-end beams for which a softened strutand-tie model is shown to give reasonable predictions of shear strength. In this context, it is interesting to note that neither Eurocode 2 nor the draft Model Code 2010 relate the concrete compressive strength in struts to their orientation or the strain in the ties as suggested by Collins et al. (2008). This would seem to be a significant omission since there is considerable evidence that the compressive strength of struts in short span beams depends upon the ratio of the shear span to the effective depth. For this reason, the background document (BSI, 2010) to the UK National Annex to Eurocode 2 limits the use of the strut-and-tie method to cases where the ratio of the shear span to the effective depth is less than $1 \cdot 5$.

The remaining paper on shear concerns the behaviour of nonseismically detailed beam-column joints under cyclic loading (Joyklad et al., 2012). This is an important issue as many reinforced concrete framed structures in seismic regions have not been designed to modern seismic codes. The article by Park et al. (2012) is also concerned with the seismic design of reinforced concrete. It considers the modelling of confined concrete under combined axial load and bending.

The paper by Choi et al. (2012) considers the flexural performance of reinforced concrete beams with recycled aggregate. Significantly, the performance of the beams with recycled aggregates is shown to be comparable with that of beams with natural aggregate. The paper by Al-deen et al. (2012) considers the long-term behaviour of composite steel and concrete beams. The tests specimens included six simply supported specimens with a connection at mid-span and one full-scale continuous beam with a connection at the internal span. The resulting experimental data will be useful to researchers interested in investigating the lack of realism in the simplified models used for the design of connections in composite beams. The research clearly illustrates the benefits of carrying out tests on models with realistic boundary conditions where the observed behaviour can be more complex than anticipated on the basis of tests on statically determinate members.

Collectively, the papers in this themed issue illustrate the indispensable role of experimental research in the essential and continuous development of design codes. The concrete research and code-writing communities should ensure that this message is communicated to funding councils in this time of financial cutbacks and strategically targeted research programmes. 


\section{REFERENCES}

Al-deen S, Ranzi G and Vrcelj Z (2012) Long-term experiments of composite beams and connections. Magazine of Concrete Research 64(9): 847-859, http://dx.doi.org/10.1680/ macr.11.00189.

BSI (2004) BS EN-1992-1-1:2004. Eurocode 2. Design of concrete structures. Part 1: General rules and rules for buildings. BSI, London, UK.

BSI (2007) British Standard BS8110-1:1997. Structural use of concrete. Code of practice for design and construction. BSI, London, UK.

BSI (2010) PD 6687-1:2010: Background paper to the National Annexes to BS EN 1992-1 and BS EN 1992-3. BSI, London, UK

Choi WC, Yun HD and Kim SW (2012) Flexural performance of reinforced recycled aggregate concrete beams. Magazine of Concrete Research 64(9): 835-846, http://dx.doi.org/10.1680/ macr.11.00018.

Collins MP, Bentz EC, Sherwood EG and Xie L (2008) An adequate theory for the shear strength of reinforced concrete structures. Magazine of Concrete Research 60(9): 635-650, http://dx.doi.org/10.1680/macr.2008.60.9.635.

fib (2012) Model Code 2010 - Final Draft, Volume 2, Bulletin no. 52. fib, Lausanne, Switzerland.

Joyklad P, Pimanmas A and Dhakal RP (2012) Cyclic performance of beam-column joints with extended column fixed at base. Part I: experimental investigation. Magazine of Concrete Research 64(9): 805-823, http://dx.doi.org/10.1680/ macr.11.00083.

Lu WY, Lin IJ and Yu HW (2012) Behaviour of reinforced concrete dapped-end beams. Magazine of Concrete Research 64(9): 791-803, http://dx.doi.org/10.1680/macr.11.00116.

Motamed J, Al-Hussaini A and Alani AM (2012) Shear design of HSC beams with combination of links and horizontal web steel. Magazine of Concrete Research 64(9): 779-789, http:// dx.doi.org/10.1680/macr.11.00047.

Park JY, Lee YH and Scanlon A (2012) Confined concrete model for columns under combined axial load and bending. Magazine of Concrete Research 64(9): 825-834, http:// dx.doi.org/10.1680/macr.11.00027.

Vaz Rodrigues R (2012) Influence of yielding of flexural reinforcement on shear transfer through cracks. Magazine of Concrete Research 64(9): 751-765, http://dx.doi.org/10.1680/ macr.11.00070.

Vaz Rodrigues R, Muttoni A, Fernández Ruiz M (2010) Influence of shear on rotation capacity of reinforced concrete members, without Shear Reinforcement. ACI Structural Journal 107(5): 516-525.

Yang KH, Sim Jl, Kang JH and Ashour AF (2012) Shear capacity of monolithic concrete joints without transverse reinforcement. Magazine of Concrete Research 64(9): 767778, http://dx.doi.org/10.1680/macr.11.00107. 